\title{
A Study on Corporate Image, Customer Satisfaction and Brand Loyalty in the Context of Retail Stores
}

\author{
Selda Ene ${ }^{1} \&$ Betül Özkaya ${ }^{2}$ \\ ${ }^{1}$ Vocational High School of Social Sciences, Marmara University, İstanbul, Turkey \\ ${ }^{2}$ Faculty of Communication, Marmara University, İstanbul, Turkey \\ Correspondence: Selda Ene, Vocational High School of Social Sciences, Marmara University İstanbul, Turkey. \\ Tel: 90-53-2374-9686. E-mail: seldaene@marmara.edu.tr
}

Received: March 2, 2014 Accepted: May 26, 2014 Online Published: June 24, 2014

doi:10.5539/ass.v10n14p52

URL: http://dx.doi.org/10.5539/ass.v10n14p52

\begin{abstract}
In the intense competitive environment, in order for a retail store to gain strength and competitive edge, it needs to possess a strong corporate image and to keep and satisfy its customers. The retail store will create a successful brand loyalty due to its ability to be equipped with a strong corporate image and to increase customer satisfaction.

Key elements that are effective in creating brand loyalty that enables the retail store to have a competitive edge, have an order of corporate image of the business, customer satisfaction, customer expectations, the product or the service quality that is perceived and perceived value. Setting from this point on, this study addresses corporate image and customer satisfaction elements that effect brand loyalty and surveys have been conducted with customers who shop from the retail stores in Istanbul and the relationship between customer satisfaction and brand loyalty is examined with regression analysis.
\end{abstract}

Keywords: retail stores, corporate image, customer satisfaction, brand loyalty

\section{Introduction}

In 1990s and 2000s, the retail sector has gotten into a livelier motion with the modern shopping streets and centers entering the market. With chain stores combining franchising, hypermarkets and supermarkets, the sector has transformed into a more modern structure with the increase of organized retailers who have planned, systematic, centralized management of corporate structure that records everything (Yalçın, Erdoğmuş, \& Çobanoğlu, 2009, p. 384). Thanks to the developments in retail sector, a significant increase has been observed in sustainable performance of Turkey's national economy. From 1987 to first quarter of 2007, the share of Turkish Retail Sector within Gross Domestic Product varies between 17.36\%-20.97\%. While the total sales of retail sector are $\$ 136.9$ billion in 2006, this figure for 2010 is realized as \$199 billion (K1liç \& Şenol, 2010, p. 45).

While the increase in organized retailer ship in 2007 realized in EU as $2 \%$, this rate was $10 \%$ in Turkey. According to a study, conducted by Nielsen Company, the number of hyper super and chain market stores in Turkey in 1998 was 2135 and this has increased to 8252 in 2008 . Through the same period, the number of groceries and medium-sized markets has decreased from 167 thousand to 128 thousand. (Boran, 2008, p. 22). Prepared by Eva Real Estate Appraiser Consultation and Akademetre Research and Strategic Planning, "AVM (Shopping Mall) Potential Requisite Analysis" has showed that, the number of AVMs in Turkey has increased from 106 (2005) to 263 (2010) and to 279 in 2011. It is observed that the sector is growing with an average of $20-25 \%$ per year (Bloomberg, HT, 2011). In its report where the latest state of Turkish retail sector is analyzed, world's leader professional service firm, Deloitte stated that the size of Turkish retail sector has reached to $\$ 187$ billion in 2010 and predicts that it will reach $\$ 250$ billion in 2014. In 2010, the biggest share belonged to food, with $\$ 96$ billion and it is followed by home appliances with $\$ 26.5$ billion, textile with $\$ 24.3$ billion and technology retail market with $\$ 7.3$ billion (Deloitte Leadership Institute, 2013).

In light of all these developments and in competitive retail sector, current customers need to be kept and the brand loyalty needs to be established in order to create a sustainable competitive edge. Businesses now point out that keeping their own customers are more profitable, compared to gaining new customers. For instance, 
Customer Service Institute surmises that gaining a new customer is five times more costly than serving an existing customer (Guiltinan, Paul, \& Madden, 1994, p. 117).

According to European Customer Satisfaction Index, the elements that have effect on the creating of brand loyalty are corporate image of the business, customer satisfaction, customer expectations, the product or the service quality that is perceived (Atalık, 2005, p. 3). Enabling customer satisfaction is a key topic for the businesses because customer satisfaction creates loyalty. In that, a better business performance is established. (Gronholdt, Martensen, \& Kristensen, 2000, p. 509). The most significant contribution that satisfied customers make to a business is becoming a loyal customer (Köse, 2007, pp. 61-62). Setting from this purpose, this study analyses corporate image, customer satisfaction and brand loyalty within the context of retail stores and surveys have been conducted with customers who shop from the retail stores in Istanbul and the relationship between corporate image, customer satisfaction and brand loyalty is examined with regression analysis.

\section{The Corporate Image of Retail Stores}

Image is a notion which an individual holds with regards to another individual, group or organization. In other words, image is an impression which an individual or a group seeks to create or strike upon others regarding himself/herself/itself. On the basis of these explanations, corporate image, shortly, can be explained as all kinds of impressions that the community makes about a corporation. Corporate image is a valuable, tangible entity which is hard to imitate and it can help to obtain superior, sustainable financial performance (Marteson, 2007, p. 546).

The purpose of the corporate image is to enable the clear, accurate understanding of the firm. Corporate image is about emotions and therefore, the image about the corporation differs from person to person. The important thing for the image is to ensure that a clear and a good will are created regarding the corporation. It is possible for partial or inaccurate information to affect the corporate image in a negative way. Having a good reputation for the community that the corporation operates in elicits the creation of positive image in the eyes of target audience and therefore enabling the firm to increase its operations and its profits (Okay, 1998, p. 49).

Corporate image is comprised of four key elements in which the corporate image has influence on employees, target groups (customers, partners) and community. These are thoughts about the corporation, recognition of the corporation, reputation of the corporation and the comparability of the firm with its competitors. In this context, corporate image is established as a result of creating corporate image efforts. On that note, the corporate image notion in today's world needs to include details that concern all vital processes of the corporation, starting from the corporations' reason of being to realizing its main purposes and its interaction with external environment (Regenthal, 1992; Yalçın, 2010, p. 28).

In order to create a positive and desirable corporate image, "establishment of an infrastructure" and accordingly "creation of external and inner image" is needed. The factors that create aforementioned infrastructure are mission and vision definitions of the corporation. Secondly, in order to establish a strong corporate image, one needs to create an external image for the corporation. Creation of external image consists of 7 main factors. These are: customer satisfaction, product quality, tangible image, advertisement, sponsorship, media relations and social responsibility. The third aspect of corporate image creation is establishing a corporate image targeted at inner audience. The main function of a positive corporate image creation is to attract the customer. However, this too will not be adequate. Attracted by the external image the customer who is visiting the corporation is being influenced by the employees who he/she contacts with and determines whether the employee behaviors harmonize with the external image of the corporation (Bolat, 2006, pp. 112-122). Therefore there are circumstances where the employees affect the corporate image or cases in which the employees are directly affected by the corporate image (Bal, 2012, p. 223).

According to Keller, on the other hand, the arbiters of the corporation's image are combined in ten groups. These are; the corporation itself, its social circle, its employees, reliefs that the corporate contribute to, the products of the corporation, its distribution channels, after sales services and tis communications (Keller, 1998; Tığlı, 2003, p. 248). The most important association which the consumers perceive in connection with a particular corporation should be analyzed in four aspects: product image (common product features, benefits or attitude), service image (individuals and relations), nationality image (values and programs relating to social wellness) and credibility image (credibleness and experience). If we think of these applicant individuals as potential consumers in business market, these images might have influence on the applicants. For this very reason, it is possible to speak of these four corporate image aspects (corporate product image, corporate service image, corporate nationality image and corporate credibility image) (Keller, 2000; Tsai \& Yang, 2010, p. 50).

The corporate image answers the question of "what do these people think of corporations?" It is possible for the 
image to involuntarily arise after deliberative efforts of the corporation or as a result of its actions (Dowling, 2004; Eryllmaz, 2008, p. 159). They emphasize that the corporate image can appear in an instant, but corporate reputation builds on through time. In other words, the corporate image is the last thought of the stakeholders, regarding the corporation. However, reputation relies on a behavior cluster, comprised of previous, current and future potential actions of the corporation. (Eryllmaz, 2008, p. 159). Further, when compared to image, which can be briefer, reputation can be stated as a prestige in the long term perspective of the corporation, due to its nature (Fombrun \& Martenson, 2007, p. 546).

Even though it is alternately utilized by many authors, there are two other different notions that share similarity with corporate image. One of these is corporate reputation and the other one is corporate product. (Herrbach, Mignonac, Gatignon, Öz, \& Bulutlar, 2009, p. 40). Corporate image is further imposed by the administration and it is implicit in its messages where the aim is to influence external world. Therefore, the corporate image moves from the administrators to the outer world. The repute of the corporation is, in a sense, the feedback of these messages. Put it differently, the fame of the corporation is made of feedback messages regarding the distinctive, consistent features, given by all relevant external stakeholders, customer, competitors, suppliers, etc. (Öz \& Bulutlar, 2009, p. 40).

Corporate reputation is the perceiving method of customers, competitors, creditors, industry analysts and other individuals. A more clear definition is that the corporate reputation determines how the corporation is perceived by other people, in terms of the corporate management capacity, strategies, financial status, social and communal responsibilities, the value of long term investments, its activity in the competition, development level, the quality of its personnel and attraction of qualified employees and the corporate reputations is gauged by these factors. Corporate reputation is the recognition method of the corporations by customer, supplier or competitive environment. At this point, the difference between corporate image and corporate reputation comes into play (Karakılıç, 2005, p. 183).

\section{Customer Satisfaction in Retail Stores}

Since customer satisfaction is a subjective concept, it can be stated that a total definition consensus has not been reached in this matter. Therefore many definitions of customer satisfaction have been developed. According to one definition, customer satisfaction is defined as a subjective circumstance where a presented product or service (in other words chosen alternative-in this case, the store) meets or exceeds the expectations (Engel, Blackwell, \& Miniard, 1990, p. 47). According to another definition, customer satisfaction reflects the slight difference between customers' before sales expectations and after sales experiences, efficiently meeting and in fact, exceeding the customer expectations with products and services (Aktepe, Baş, \& Tolon, 2009, p. 11).

According to Oliver, customer satisfaction is the gratification feeling, derived by the feedback as the result of consumption. In other definition, Oliver defines satisfaction as "the pleasing result" (Oliver, 1999; Usta \& Memiş, 2009, p. 89). According to another definition, customer satisfaction is the relationship between customers' perceived performance of a product or a service and their expectations. Accordingly, the concept of customer satisfaction is a function of customer expectations. Customer satisfaction depends on their comparisons with what they are provided with and their expectations. If the factors provided are in line with the expectations, the customer will be satisfied; if not, he/she feels disappointed and will not be satisfied. More, if the presented factor is above expectations, the customer will have a high level of satisfaction. Those who have high level of satisfaction, not only change their positions with regards to another presentations, but also bring others with them and hold their ground before moving on to another business. Therefore high level customer satisfaction is important for businesses and provides many benefits for the business. Among these benefits are; improving brand loyalty, decreasing price flexibility, decreasing marketing and new customer procurement costs, decreasing manufacturing cost depending on mass manufacturing, developing efficient advertisement, enhancing brand image and reputation (Uta \& Memiş, 2009, p. 89).

Meeting customers' expectations and customer satisfaction is only possible through accurate knowledge of customer expectations. This can only be accomplished by establishing a continuous and accurate communication with the customers. When the customers are not satisfied, the most sensible behavior would be to communicate with the client, understand his/her dissatisfaction and resolve these factors.

Provided that the businesses operate within a system, customer satisfaction can be perceived as an indicator of businesses' responsibility understanding, in terms of presented product or service that acts as a feedback. However, due to customers' inwardness, influenced by the very notion of being a customer and their exteriority, rising from their connections with other customers, variety and market mobility; the corporations determine the customer satisfaction according to customers' features, status and special conditions and they seek to enable the 
continuity of customer satisfaction or to increase their profitability. Consequently, along with product or service performance and quality, the relationships with the customer, attitude and behaviors towards customer should not be neglected. Generally, customer services as part of customer orientation and customer satisfaction and customer delight is sought.

It is not possible to enhance this factor without determining customer satisfaction level or to increase the quality of services and products presented to the customer. In determination of customer satisfaction, steps presented below can be followed (Aktepe et al., 2009, pp. 11-12).

$>$ Presenting services on time, ensuring that the people come together and show analytical approaches.

Directors encourage their employees about reporting their failures. This method gives an opportunity to find a quick solution for the failure and therefore improves customer satisfaction.

$>$ Encouraging customers to get in touch with the firm when things go wrong.

$>$ Not handing out business cards to the customers and procurement of toll free services.

$>$ Leaving surveys in customer visits.

The adverse point of this technique is that reply rate can be low. If a system can be established where a customer wins an award when they complete a survey and send it via post, the reply rate will increase. Moreover, the business will receive a feedback.

$>$ Reaching out to customers who have previously contacted this service.

This method gives the opportunity to reach out to customers who left unsatisfied or those who have not completed their surveys.

\section{$>$ Calling of randomly picked customers by directors.}

In order to keep the customers loyal and keep them away from the competition, businesses need to continuously follow their claims, needs and expectations and variations of these in the present fierce competition environment. Those businesses that implement customer service policies by establishing successful programs will satisfy their customers and serve as a model for their competition and the sector.

Ever changing desires, needs, population rate of the customers makes it hard for the business to predict their attitudes and meet their expectations. On the basis of these factors, the corporations need to exceed customer satisfaction and focus on creating measurable brand loyalty (Weiwei, 2007, p. 59).

\section{Brand Loyalty in Retail Stores}

In recent years, with the increase of competition in retail markets, retailers need to attract consumers, need to keep them and need to focus on developing various strategies. The main purpose of many retailers is to make their customers more loyal (Yücel \& Yücel, 2012, p. 96). The reason is that, contrary to products, the customers are the lifeline and the most important assets of the corporation.

Loyalty is born as a result of customer satisfaction (Martenson, 2007, p. 544). For this reason, a satisfied customer is inclined to perform re-purchase behavior and intent and to be a loyal customer.

Brand loyalty represents purchase of a particular product or brand and implies that the customer will not search for another product or product alternative when there is a requirement. When addressed in this sense, there is a strong bond between customer satisfaction and loyalty. When the satisfaction feeling is continuous, loyal customers are created. 21). In short, brand loyalty is recurrent purchase behavior. Establishing a brand loyalty on consumers is a target every retailer seeks to reach. Because this means steady sales or preservation of market share (Ateşoğlu, 2003, p. 75).

In defining and measuring brand loyalty, it is possible to mention two main approaches that are used in marketing studies (Gün et al., 2012). These approaches analyze brand loyalty, sometimes explaining with only behavioral or attitudinal aspect and sometimes utilizing both approaches. (pp. 143-145; Demir, 2012, p. 103). This approach about brand loyalty, in which the behavioral and attitudinal extend is comprised, is discussed as hybrid loyalty in literature (Kabiraj \& Shanmuga, 2010, p. 288).

In behavioral perspective, there is a purchase commitment and it is expressed with purchase rate (Anisimova, 2010, p. 492). In other words, the point in question is the iteration of purchase behavior and it can be said that it relies on the history of purchase behavior (Dursun, 2011, p. 102). According to the approach which analyzes loyalty only with its behavioral aspect, brand loyalty represents consumers' purchase frequency, amount and recurring purchase behavior (Kabiraj \& Shanmugan, 2010, p. 291). 
In attitudinal approach, there is a loyal, safe and emotional content. It comprises emotional and cognitive reactions that lie beyond recurring purchase behavior. (Anisimova, 2010, p. 492). Attitudinal brand loyalty is developed by preference, purchase intent, preferential favor of business, resisting better alternatives, readiness to pay more or additional fee for the product or service, feeling of connection and intentness of advising (Tosun, 2010, p. 144).

In literature, it is frequently acknowledged that behavioral or attitudinal approaches, on their own, are insufficient in expressing brand loyalty and both approached need to be evaluated together (Özdemir \& Koçak, 2012 , p. 103). As shown in works in which the brand loyalty creation process is analyzed, an approach depending on hybrid base needs to be examined by discussing the consumers' attitudes towards the brand and recurring purchase behaviors.(Özdemir \& Koçak, 2012, p. 133).

Customer satisfaction and brand loyalty are regarded as substantial in factors that lead business to success. Today, much of corporations' marketing strategies and budgets focus on attracting new customers for the business. This has an adverse effect on corporations' profitability. The reason why the marketing strategies focus on customers, who are loyal to the corporation, is that it is much of a low-cost for a corporation to keep their current customers other than attracting new ones. Another important factor for the retailers, customer satisfaction and brand loyalty not only can be created by using a retail hybrid in the point of purchase, but also through a product or a service (Yalçın et al., 2009, p. 388).

The studies show that a $5 \%$ increase in current customers' expenditures for products can increase the corporation's profits up to $25 \%$. Therefore, in order to determine their loyalty and satisfaction levels towards corporate products and providing customer satisfaction, establishing continuous communication with the customers and observing and realizing customers' needs and requirements will be beneficial for the corporations. Another reality that the studies present is that even in the most developed countries, only $50 \%$ of unsatisfied customers protest their dissatisfaction to the corporation. Besides, customers who have dissatisfaction towards the products have the potential to influence other customers. A recent study, conducted by General Electric, shows that positive or negative rumors are two times more efficient than advertisements.

In any sector where a competitive environment exists, current customers need to be kept and the brand loyalty needs to be established in order to create a sustainable competitive edge. In this context, there is a positive relationship between customer satisfaction and brand loyalty. While the level of customer expectations represents the level of customer satisfaction, the probability of that customer visiting the store again and again shows the customer's loyalty to the corporation. Every loyal customer is a satisfied customer, but every satisfied customer might not be a loyal customer (Çatı \& Koçoğlu, 2006, p. 173).

The strong bond between brand loyalty and customer satisfaction has been presented in various studies. The creation of customer loyalty process initially depends on customer satisfaction. In order for a consumer to be interpreted as a customer, his/her connection with the corporation needs to rise to a continuity level. At this point only it is possible to form a brand loyalty, as a result of customer satisfaction. In this sense, it is acknowledged that there is a linear relationship between customer satisfaction and brand loyalty. During this relationship between two notions, the brand loyalty increases as the customer satisfaction increases and vice versa. The studies conducted in this field focus on whether the customer satisfaction constantly influence brand loyalty. If a customer leaves the retail store feeling satisfied after every visit and is not influenced by external variables, he/she is becoming the igniter of loyalty. In this context, due to the possibility that the satisfied customers might still leave the corporation, customer satisfaction might be essential, but not sufficient for the creation of brand loyalty. Customer satisfaction is only critical for brand loyalty, when it reaches a high level (Coşkun, 2007, pp. 58-59). In addition to these, according to the results of many studies, it has been observed that corporate image and corporate reputation also positively influence brand loyalty. In other words, in establishing a brand loyalty, corporate image and corporate reputation are also influent and essential. (pp. 499-513; Marangoz \& Biber, 2007, p. 173; Dursun, 2011, p. 97).

\section{A Study on Determining the Relationship between Corporate Image, Customer Satisfaction and Brand Loyalty in the Context of Retail Stores}

While determining the relationship between corporate image, customer satisfaction and brand loyalty in the context of retail stores, variables used by previous studies have been taken as examples and a research model has been established by integrating these to the study. As previous studies, the study conducted by Martenson in 2007, by Weiwei in 2007 and by Kesic, Kraljevic \& Vlasic in 2005 have been taken as examples and a research model has been developed. 


\subsection{Purpose, Scope of the Study}

Key elements that are effective in creating brand loyalty that enables the retail corporations to possess a competitive edge are customer satisfaction, corporate image, customer expectations, perceived service quality and product quality. Setting of from this point, this study analyzes retail store corporate image and customer satisfaction which have positive influences on brand loyalty. In the implementation section of the study, the relationship between corporate image, customer satisfaction and brand loyalty in the retail stores (goods and garment retail stores) in Istanbul.

The survey has been conducted with individual who shop from the retail food and garment stores, located in İstanbul, Turkey and the corporate image of the retail stores in the eyes of the customers are evaluated. Whether the corporate image relates to customer satisfaction and brand loyalty is tested with applied statistical analyses. Initially, the focus was on the factors that create corporate image. The variables that comprise the corporate image of the retail store are divided into sub variables with the factor analysis. Afterwards, the relation of these variables comprising the corporate image with customer satisfaction and brand loyalty is examined with regression analysis.

\subsection{Research Methodology}

The research methodology is made of the limits of research, the research model and the bulk sample selection of the research.

\subsubsection{Limits of Research}

In this study, from the factors that affect "brand loyalty", "retail store corporate image" and "customer satisfaction" variables are discussed and a model is established for examination. The limits for the main bulk of the research are that it is made of individuals that are over 18 years of age, capable of making a self-directed shopping decision and shop from retail stores between $10 \mathrm{AM}$ and 6 PM for various purposes. In this context, a survey has been conducted with 246 individuals who shop from retail goods and garment stores in Istanbul and retail stores' corporate image has been evaluated with regards to the consumers.

\subsubsection{Research Model}

Model has been developed by inspiring from Martenson's 2007 "Corporate Image, Customer Satisfaction and Commitment Relationship-Perception of the Store by the Customer in terms of Brand, Store Brand and Manufacturing Brands; Wiewie's December 2007 "The Effect of Corporate Reputation and Corporate Image on Brand Loyalty-An Observation; (Kesic, Kraljevic, \& Vlasic's, 2005) "The Image of Retail Store as a Competition Factor" studies (Kesic, Kraljevic, \& Vlasic, 2005, p. 368; Geray, 2007, p. 546; Weiwei, 2007, p. $58)$.

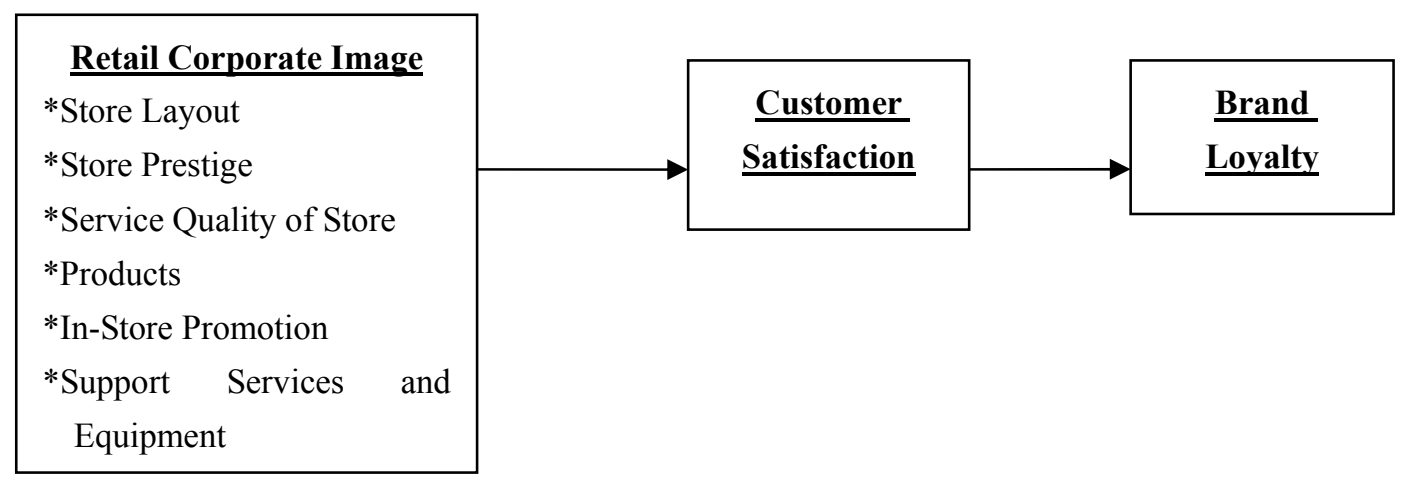

Figure 1. A study on corporate image, customer satisfaction and brand loyalty relationship in the context of retail stores

As seen in Figure 1, a research model has been developed in order to examine the relationship between "Retail Corporate Image", "Customer Satisfaction" and "Brand Loyalty". 
Table 1. Retail corporate image, customer satisfaction and brand loyalty scale table

\begin{tabular}{lll}
\hline Variable & & Source \\
\hline & Store Location & \\
& Store Prestige & \\
Retailer Corporate Image & Service Quality of Store & Martenson, 2007; \\
& Products & Weiwei (December 2007) \\
& In-Store Promotion & Kesic, Kraljevic, \& Vlasic (January 2005) \\
& Support Services and Equipment & \\
& & Coşkun, (2007) \\
Customer Satisfaction & & Çatı \& Koçoğlu, (2006) \\
& & Anisimova, (2010) \\
& & Kabiraj \& Shanmugan, (2010) \\
Brand Loyalty & Dursun, (July 2011) \\
& & Demir, (2012) \\
& & Wansink \& Seed, (February 2001) \\
& Özdemir \& Koçak, (2012) \\
\hline
\end{tabular}

As seen in Figure 1, references for the scale that has been established for "Retail Corporate Image", "Customer Satisfaction" and "Brand Loyalty" is presented with a table.

The hypotheses of the study are included below. By discussing these hypotheses, sub-hypothesis is created and analyses are made.

$\mathbf{H}_{1}$ : There is a suggestive relation between corporate image and customer satisfaction.

H2: There is a suggestive relation between brand loyalty and customer satisfaction.

\subsubsection{Determination of Study Bulk Sample}

Implementation is realized by using face to face survey, conducted with consumers who shop from retail stores. In the study, data is gathered by using convenience sampling.

\subsection{Findings of the Study}

The analyses of the study have been examined in two sections: definitional and deductional.

\subsubsection{Definitional Analysis Findings}

The sample audience is made of consumers who shop from retail stores in Istanbul. A survey has been conducted with 246 individuals who shop from retail goods and garment stores in Istanbul. The consumers are comprised of 246 individuals of which the $62.9 \%$ are women and $35.9 \%$ are men. The age groups and distributions of participants are as follows: "Ages between 18-25"-42.3\%; "26-35"-28.6\%; "36-45"-17.3\%; and "46-55"-10.1\% $53,2 \%$ of the participants are single, while $39.5 \%$ of them are married. Education status of the participants is as follows: $46 \%$ high school; $36.3 \%$ associate degree; $8.1 \%$ university and $6.9 \%$ post graduate degree. Their average income amounts and distributions are as follows: 500-1000: 43.1\%; 1001-2000: 34.7\%; 2001-3000: $13.3 \%$ and 3001-4000: 5.2\%.

Initially, a factor analyses has been implemented on the scales that are included in the research and credibility tests are carried out individually on the factor groups In order to examine the reliability of the scales, Cronbach's Alpha Coefficient is referenced.

"Retailer Corporate Image" variables scale is made of 19 questions. Nineteen questions have been subjected to factor analysis, factor loads have been subjected to evaluation of a value near 0.50 and above. For 19 variables, 6 factor groups are manifested. For "Retailer Corporate Image" variables comprised of 19 variables, at the end of the credibility analysis which has been performed in a significance level of 0.05; Cronbach's Alfa Value has been determined as 0.861. "Brand Loyalty" scale is made of 4 questions and identically, has been subjected to the factor analysis. As a result of the factor analysis, it has been observed that every question under the "Brand Loyalty" scale is gathered under an individual factor group. For "Brand Loyalty" scale, at the end of the credibility analysis which has been performed in a significance level of 0.05; Cronbach's Alfa Value has been determined as 0.782. "Customer Satisfaction" scale is made of 5 questions and similarly, has been subjected to the factor analysis. As a result of factor analysis, it has been observed that every question in the "Customer 
Satisfaction" scale is gathered under the same factor group and after the credibility analysis of level 0.05 , Cronbach's Alfa Value is found to be 0.889. In this regard, it has been observed that the study results are reliable.

Alpha value carries values between 0 and 1 and it desired for the admissible value to be at least 0.7 (Nunnally, 1978, p. 245). Therefore, it is observed that the credibility of every scale is high.

In the factor analysis, which has been performed to the 'Retailer Corporate Image' which consists of 19 questions; when Kaiser-Meyer-Olkin (KMO) sample efficiency test is applied; relevance value is found to be 0,000 and $\mathrm{KMO}$ value is found to be 0,858 . When the Kaiser-Meyer-Olkin sample efficiency test is applied to "Customer Satisfaction" scale, significance value is found to be 0.000 and KMO value is found to be 0.838 . When the Kaiser-Meyer-Olkin sample efficiency test is applied to "Brandl Loyalty" scale, significance value is found to be 0.000 and $\mathrm{KMO}$ value is found to be 0.735 .

The test of factor analysis of practicability to any data set is measured with 'Kaiser-Meyer-Olkin (KMO) sample efficiency test. The KMO values between 0.5-1.0 are deemed to be acceptable (Altunmışık, Coşkun, Bayraktaroğlu, \& Yıldırım, 2005, p. 217). Therefore, these values are found to be sufficient for factor analysis.

Table 2. "Retailer Corporate Image" variables factor analysis results

\begin{tabular}{|c|c|c|c|c|}
\hline $\begin{array}{l}\text { Factor } \\
\text { Group }\end{array}$ & $\begin{array}{l}\text { Factor Group } \\
\text { Name }\end{array}$ & $\begin{array}{l}\text { Credibility of Factor Group } \\
\text { (Cronbach's Alfa Coefficient) }\end{array}$ & Corporate Image Variables & $\begin{array}{l}\text { Factor } \\
\text { Loads }\end{array}$ \\
\hline \multirow{3}{*}{ Factor 1} & \multirow{3}{*}{ Store Layout } & \multirow{3}{*}{0,640 . } & $\begin{array}{l}\text { - In store layout is practical and } \\
\text { orderly }\end{array}$ & 0,734 \\
\hline & & & $\begin{array}{l}\text { orderly } \\
\text { - Corridors between aisles have } \\
\text { enough space }\end{array}$ & 0,756 \\
\hline & & & - Suitable for shopping with children & 0,639 \\
\hline \multirow{3}{*}{ Factor 2} & \multirow{3}{*}{ Store Prestige } & \multirow{3}{*}{0,648} & $\begin{array}{l}\text { - There are high priced and quality } \\
\text { products in the store }\end{array}$ & 0,723 \\
\hline & & & - Known and prestigious store & 0,664 \\
\hline & & & $\begin{array}{l}\text { - Meets the consumers' desires and } \\
\text { needs with sufficient personnel }\end{array}$ & 0,517 \\
\hline \multirow{5}{*}{ Factor 3} & \multirow{5}{*}{$\begin{array}{l}\text { Service Quality of } \\
\text { Store }\end{array}$} & \multirow{5}{*}{0,680} & - Service flow is smooth and fast & 0,618 \\
\hline & & & - Prices meet the presented values & 0,547 \\
\hline & & & $\begin{array}{l}\text { - There are social responsibility } \\
\text { campaigns }\end{array}$ & 0,532 \\
\hline & & & $\begin{array}{l}\text { - The store personnel are problem } \\
\text { solvers }\end{array}$ & 0,497 \\
\hline & & & - Employees are good-humored. & 0,450 \\
\hline \multirow{3}{*}{ Factor 4} & \multirow{3}{*}{ Products } & \multirow{3}{*}{0,641} & $\begin{array}{l}\text { - Desired products and brands can be } \\
\text { found easily in the store }\end{array}$ & 0,758 \\
\hline & & & $\begin{array}{l}\text { - In store layout enables easy access for } \\
\text { products }\end{array}$ & 0,516 \\
\hline & & & - Wide product range & 0,481 \\
\hline \multirow{2}{*}{ Factor 5} & \multirow{2}{*}{ In-Store Promotion } & \multirow{2}{*}{0,561} & $\begin{array}{l}\text { - There are remarkable and intriguing } \\
\text { advertisements in the store }\end{array}$ & 0,759 \\
\hline & & & $\begin{array}{l}\text { - The promotions in the store are } \\
\text { satisfying }\end{array}$ & 0,723 \\
\hline \multirow{3}{*}{ Factor 6} & \multirow{3}{*}{$\begin{array}{l}\text { Support Services and } \\
\text { Equipment }\end{array}$} & \multirow{3}{*}{0,566} & $\begin{array}{l}\text { - There are sufficient number of } \\
\text { shopping carts in the store }\end{array}$ & 0,687 \\
\hline & & & $\begin{array}{l}\text { - There is no difficulty in product } \\
\text { returns }\end{array}$ & 0,668 \\
\hline & & & $\begin{array}{l}\text { - The coziness is always at the desired } \\
\text { level in the store }\end{array}$ & 0,462 \\
\hline
\end{tabular}

As seen in Table 2, six factor groups are included as a result of the factor analysis regarding "Retailer Corporate Image" variables. Also, it has been examined that the six factors which has been obtained in the study has 
attested the $63.33 \%$ of total variance.

Table 3. "Customer Satisfaction" factor analysis results

\begin{tabular}{|c|c|c|c|c|}
\hline $\begin{array}{l}\text { Factor } \\
\text { Group }\end{array}$ & $\begin{array}{l}\text { Factor } \\
\text { Group Name }\end{array}$ & $\begin{array}{l}\text { Credibility of Factor Group } \\
\text { (Cronbach's Alfa Coefficient) }\end{array}$ & Customer Satisfaction Variables & Factor Loads \\
\hline \multirow{4}{*}{ Factor 1} & \multirow{4}{*}{$\begin{array}{l}\text { Customer } \\
\text { Satisfaction }\end{array}$} & \multirow{4}{*}{0,889} & $\begin{array}{l}\text { - I was happy to shop from this store } \\
\text { - Retail store is an eligible and } \\
\text { prestigious store }\end{array}$ & $\begin{array}{l}0,878 \\
0,842\end{array}$ \\
\hline & & & $\begin{array}{l}\text { - My choice of this retail store was } \\
\text { correct and logical }\end{array}$ & 0,840 \\
\hline & & & - I don't regret choosing this retail store & 0,811 \\
\hline & & & $\begin{array}{l}\text { - Presented products and services meet } \\
\text { my expectations }\end{array}$ & 0,793 \\
\hline
\end{tabular}

As seen in Table 3, factor group and the credibility of the factor group of "Customer Satisfaction" factor analysis is presented, along with factor loads of the variables comprising the factor group. "Customer Satisfaction" scale has come to surface for only one factor group and it has been observed that it attests $69.401 \%$ of the total variance.

Table 4. "Brand Loyalty" factor analysis results

\begin{tabular}{|c|c|c|c|c|}
\hline $\begin{array}{l}\text { Factor } \\
\text { Group }\end{array}$ & $\begin{array}{l}\text { Factor } \\
\text { Group Name }\end{array}$ & $\begin{array}{l}\text { Credibility of Factor Group } \\
\text { (Cronbach's Alfa Coefficient) }\end{array}$ & Brand Loyalty Variables & Factor Loads \\
\hline \multirow{4}{*}{ Factor 1} & \multirow{4}{*}{ Brand Loyalty } & \multirow{4}{*}{0.782} & $\begin{array}{l}\text { - I would recommend this store to } \\
\text { others }\end{array}$ & 0.902 \\
\hline & & & $\begin{array}{l}\text { - I would tell positive things to } \\
\text { my acquaintances about this store. }\end{array}$ & 0.874 \\
\hline & & & $\begin{array}{l}\text { - I would continue shopping from } \\
\text { this retail store }\end{array}$ & 0.770 \\
\hline & & & $\begin{array}{l}\text { - Even the other retailer stores have } \\
\text { discounts, I would continue } \\
\text { shopping from this store. }\end{array}$ & 0.586 \\
\hline
\end{tabular}

As seen in Table 4, factor group and the credibility of the factor group of "Brand Loyalty" factor analysis is presented, along with factor loads of the variables comprising the factor group. "Brand Loyalty" scale was realized for only one factor group and it has been observed that it attests $62.813 \%$ of the total variance.

\subsubsection{Deductional Analysis Findings}

The deductional analysis of the study has been examined as follows:

\section{Abbreviations for Dependent Variables;}

Brand Loyalty: BL

Customer Satisfaction: CS

\section{Abbreviations for Independent Variables;}

Store Layout: SL

Store Prestige: SP

Service Quality of Store: SQS

Products: $\mathrm{P}$

In-Store Promotion: ISP

Support Services and Equipment: SSE 
It has been agreed that the variables of six factor groups that are obtained as a result of "Retail Store Corporate Image" factor analysis, comprise the independent variables. The regression formula explaining the relationship between "Retail Corporate Image and Customer Satisfaction" explained with the:

$$
\mathrm{CS}=0.057+0.123 \mathrm{SL}+0.278 \mathrm{SP}+0.199 \mathrm{SQS}+0.174 \mathrm{P}+0.187 \mathrm{ISP}+0.127 \mathrm{SSE}
$$

equation.

Implementation is realized by incorporating all variables to stepwise regression method. Due to various iterations, the model has emerged. In this research, as a result of the iterations of stepwise method (result of 7 iteration), final model has been presented.

Table 5. Regression analysis model summary of the relationship between corporate image and customer satisfaction, in the context of retailer stores

\begin{tabular}{lllll}
\hline Model & $\mathbf{R}$ & $\mathbf{R}^{2}$ & Corrected $\mathbf{R}^{2}$ & Standard Error of Estimate \\
\hline 7 & 0.780 & 0.608 & 0.595 & 0.6144 \\
\hline
\end{tabular}

As seen in Table 5, the model summary that has been obtained as a result of regression analysis of the relationship between corporate image and customer satisfaction, in the context of retailer stores.

Table 6. Regression analysis ANOVA table of the relationship between corporate image and customer satisfaction, in the context of retailer stores

\begin{tabular}{lllllll}
\hline Model & & Sum of Square & Sd & Average Square & F & p-value \\
\hline 7 & Regression & 120,237 & 7 & 17,177 & 45,503 & 0,000 \\
& Balance & 77,385 & 205 & 0,377 & & \\
& Total & 197,622 & 212 & & & \\
\hline
\end{tabular}

As seen in Table 6, the ANOVA table has been obtained as a result of regression analysis of the relationship between corporate image and customer satisfaction, in the context of retailer stores.

The model which has been tested with regression analysis is statistically relevant $(\mathrm{F}=45.503$ and $\mathrm{p}=0.000)$. Because, relevance level of $F$ value is smaller than $(p<0.05), 0.05$. Our dependent variable is Customer Satisfaction: CS. It has been agreed that the variables of six factor groups that are obtained as a result of "Retail Store Corporate Image" factor analysis, comprise the independent variables. Independent variables are: "Store Layout: SL, Store Prestige: SP, Service Quality of Store: SQS, Products: P, In-Store Promotion: ISP, and Support Services and Equipment: DHD. Independent variable explains the $59.5 \%\left(\mathrm{R}^{2}\right.$ value) of the change in dependent variable.

Table 7. "Beta, Standard Error, $t, \mathrm{p}$ " value results as a result of the regression analysis of the relationship between retailer corporate image and customer satisfaction

\begin{tabular}{llllllll}
\hline Independent Variables & & SL & SP & SQS & P & ISP & SSE \\
\hline Beta Value Values & 0,057 & 0,123 & 0,278 & 0,199 & 0,174 & 0,187 & 0.0127 \\
Std. Error Value & 0,420 & 0,420 & 0,420 & 0,420 & 0,420 & 0,420 & 0.4 \\
t Value & 1,358 & 2,923 & 6,556 & 4,674 & 4,128 & 4,432 & 3,047 \\
p Value & 0,176 & 0,000 & 0,000 & 0,000 & 0,000 & 0,000 & 0,000 \\
\hline
\end{tabular}

As seen in Table 7, "Beta, Standard Error, t, p" Value Results that are obtained as a result of the regression analyses are presented.

As a result of conducted analysis; the hypothesis of "H1: There is a suggestive relation between Corporate Image and Customer Satisfaction" has been tested.

6 variables that are linked with Customer Satisfaction (Store Layout: SL, Store Prestige: SP, Service Quality of Store SQS, Products: P, In-Store Promotion ISP, and Support Services and Equipment: SSE) and for these 6 variables, H1 hypothesis has been accepted. In the increase of Customer Satisfaction; "Store Layout: SL presents 
an increase of 0.123 units, Store Prestige: SP, presents an increase of 0.278 units, Service Quality of Store: SQS presents an increase of 0.199 units, Products: P presents an increase of 0.174 units, In Store Promotion: ISP presents an increase of 0.187 units, Support Services and Equipment: SSE, presents an increase of 0.127 units.

In the second section of the model where "Customer Satisfaction" is evaluated as an independent variable and "Brand Loyalty" is evaluated as dependent variable, the relationship between "Customer Satisfaction" and "Brand Loyalty" has been analyzed. For this reason, a second hypothesis has been created ("H2: There is a suggestive relation between Brand Loyalty and Customer Satisfaction.

The regression formula of the relationship between "Customer Satisfaction" and "Brand Loyalty" is expressed with

$$
\mathrm{BL}=0.059+0.592 \mathrm{CS}
$$

equation.

Implementation is realized by incorporating all variables to stepwise regression method. Due to various iterations, the model has emerged. In this research, as a result of the iterations of stepwise method (result of 1 iteration), final model has been presented.

Table 8. Regression analyses model summary of the relationship between customer satisfaction and brand loyalty in retailer stores

\begin{tabular}{lllll}
\hline Model & $\mathrm{R}$ & $\mathrm{R}^{2}$ & Corrected $\mathrm{R}^{2}$ & Standard Error of Estimate \\
\hline 1 & 0,616 & $\mathbf{0 , 3 7 9}$ & 0,376 & 0.76258 \\
\hline
\end{tabular}

As seen in Table 8, the model summary that has been obtained as a result of regression analysis of the relationship between Customer Satisfaction and Brand Loyalty in retailer stores.

Table 9. Regression analyses ANOVA table of the relationship between customer satisfaction and brand loyalty in retailer stores

\begin{tabular}{lllllll}
\hline Model & & Sum of Square & sd & Average Square & F & p-value \\
\hline 1 & Regression & 74,916 & 1 & 74,916 & 128,824 & 0,000 \\
& Balance & 122,705 & 211 & 0,582 & & \\
& Total & 197,622 & 212 & & & \\
\hline
\end{tabular}

As seen in Table 9, the ANOVA table that has been presented as a result of regression analysis of the relationship between Customer Satisfaction and Brand Loyalty in retailer stores.

The model which has been tested with regression analysis is statistically relevant $(\mathrm{F}=128.824$ and $\mathrm{p}=0.000)$. Because, relevance level of $\mathrm{F}$ value is smaller than $(\mathrm{p}<0.05), 0.05$. Our dependent variable is Brand Loyalty BL Our independent variable is Customer Satisfaction: CS Independent variables explain the $30.9 \%\left(\mathrm{R}^{2}\right.$ value) of the change in dependent variable.

Table 10. "Beta, Standard Error, t, p" value results as a result of the regression analysis of the relationship between customer satisfaction and brand loyalty in retailer stores

\begin{tabular}{lll}
\hline Independent Variables & & CS \\
\hline Beta Value Values & 0.059 & 0.592 \\
Std. Error Value & 0.520 & 0.520 \\
t Value & 1.130 & 11.350 \\
p Value & 0.260 & 0.000 \\
\hline
\end{tabular}

As seen in Table 10, "Beta, Standard Error, t, p" Value Results that are obtained as a result of the regression analyses are presented. 
As the result of conducted analysis; The hypothesis of "H2: There is a suggestive relation between Customer Satisfaction and Brand Loyalty" has been tested.

The relation of Retailer Brand Loyalty and Customer Satisfaction has been analyzed with the regression analysis and as a consequence, $\mathrm{H} 2$ hypothesis is accepted. In the increase of Brand Loyalty (BT), Customer Satisfaction: CS, presents an increase of 0.592 units.

As the result of the conducted analysis; initially the hypothesis of "H1: There is a suggestive relation between Corporate Image and Customer Satisfaction" has been tested. It has been agreed that the variables of six factor groups that are obtained as a result of "Retail Store Corporate Image" factor analysis, comprise the independent variables. It has been observed that all of independent variables (Store Layout: SL, Store Prestige: SP, Service Quality of Store: SQS, Products: P, In-Store Promotion: ISP, and Support Services and Equipment: DHD), statistically have a suggestive impact on the dependent variable and they influence the dependent variable (Customer Satisfaction) in an adjuvant sense. Therefore, H1 Hypothesis has been accepted.

As the result of conducted analysis; secondly the hypothesis of "H2: There is a suggestive relation between Brand Loyalty and Customer Satisfaction" has been tested. It has been observed that Customer Satisfaction (Independent variable) statistically have a suggestive impact on Brand Loyalty (Dependent Variable) and it influences Brand Loyalty in an adjuvant sense. Therefore, H2 Hypothesis has also been accepted.

\section{Conclusion}

Today, organized retailing is implementing modern retail principles. Among modern retail strategies are customer orientation, strategic planning, target market orientation, integrated communication application and customer-exclusive services/products. Like in any other sector, facilitating competitive edge, establishing corporate image, creating customer satisfaction and increasing brand loyalty is essential for long term profitability.

Even though the works that are realized for increasing corporate image and customer satisfaction are initially deemed as expenditure, owing to the loyal customers, there will be a decrease in the advertisement costs of the corporation. Also, increase in loyal customers will enable more flexibility in the price adjustments of the corporation's products. Even more, new customers will be attained by word of mouth and customers' suggestions. All these endeavors are strategies that are hard to imitate by the competition. This will enable corporation to acquire competitive advantages, compared to their competitors and to improve their successes.

In modern competition environment, as consequences of the efforts made to survive and to create an image on consumers' minds, brand image is established successfully and brand loyalty is increased as a result of customer satisfaction and brand loyalty. Now, the retail businesses understand the significance of how they are perceived by their target audiences.

Setting from this purpose, this study seeks to analyze and measure how consumers perceive the corporate image variables of food and garment retail businesses in Istanbul and how and in what these variables effect customer satisfaction extend and how customer satisfaction influences brand loyalty.

The relation between "Retailer Corporate Image" and "Customer Satisfaction" has been examined with regression analysis; and 6 variables, related to "Customer Satisfaction" (Store Layout; SL, Store Prestige: SP, Service Quality of Store: SQS, Products: P, In-Store Promotion: ISP and Support Services and Equipment: SSE) has been determined. In the research results, it has been examined that all these variables comprising corporate image influence the customer satisfaction in an adjuvant sense. The relation of "Brand Loyalty" and "Customer Satisfaction" has been analyzed with the regression analysis and as a consequence, a strong relevance is attained. It has been observed that Customer Satisfaction (independent variable) influences Brand Loyalty (dependent variable) in an adjuvant sense. Therefore both $\mathrm{H} 1$ and $\mathrm{H} 2$ hypotheses have been accepted.

'Having a corporate image will be beneficial for augmentation of customer satisfaction and creation of brand loyalty'; embarking from this notion, our study concludes that the "Retailer Corporate Image" variables have positive effects on "Customer Satisfaction". Additionally, the results of our study show that customer satisfaction plays a positive, persuasive role in increasing brand loyalty.

In future studies, corporate image, customer satisfaction and brand loyalty factors can be applied to different sectors and can be quantified in online environment.

\section{References}

Aktepe, C., Baş, M., \& Tolon, M. (2009). Müşteri ilişkileri yönetimi. Ankara: Detay Yayıncılık. 
Altunışık, R., Coşkun, R., Bayraktaroğlu, S., \& Yıldırım, E. (2005). Sosyal bilimlerde araştırma yöntemleri-Spss uygulamalı. Adapazarı: Sakarya Kitabevi.

Anisimova, T. (2010). Corporate brand: The company customer misalignment and its performance implications. Journal of Brand Management, 17(7), 488-503. http://dx.doi.org/10.1057/bm.2010.7

Atalık, Ö. (2005). Havayolu işletmeleri örneğinde işletme imajının havayolu işletmesi tercihlerine ve müşteri bağlılığına olan etkisinin belirlenmesine yönelik bir araştırma. Akademik Bakış, Uluslararası Hakemli Sosyal Bilimler E-Dergisi, (7). Retrieved from http://www.akademikbakis.org/pdfs/7/Anadolu.pdf

Ateşoğlu, İ. (2003). Türkiye'nin ihracatında marka imajının etkisi. Süleyman Demirel Üniversitesi, Sosyal Bilimler Enstitüsü. Unpublished Doctoral Dissertation, Isparta.

Bal, M. (2012, Haziran). Çalışan personelin kurumsal imaj oluşumuna etkisi. Kahramanmaraş Sütçü İmam Üniversitesi, İktisadi İdari Bilimler Fakültesi Dergisi, 1(2), 219-241.

Bloemer, J., \& Ruyter, K. (1998). On the relationship between store image, store satisfaction and store loyalty. European Journal of Marketing, 32(5/6), 499-513. http://dx.doi.org/10.1108/03090569810216118

Bloomberg, H. T. (2011). Retrieved from http://www.bloomberght.com/turkiye-ekonomisi/

Bolat, O. İ. (2006, Mayıs). Konaklama işletmelerinde kurumsal imaj oluşturma süreci. Balıkesir Üniversitesi SosyalBilimler Dergisi, 15(9), 107-126. Retrieved from http://sbe.balikesir.edu.tr/dergi/edergi/c9s15/ makale/c9s15m6.pdf

Boran, Ş. (2008, Mayıs). Perakende pazarındaki son gelişmeler. AR\&GE Bülteni, 22-25. Retrieved from http://www.izto.org.tr//perakende_sebnem.pdf

Çatı, K., \& Koçoğlu, C. M. (2006). Müşteri sadakati ile müşteri tatmini arasındaki ilişkiyi belirlemeye yönelik bir araştırma. Selçuk Üniversitesi, Sosyal Bilimler Enstitüsü Dergisi, 19, 167-188. Retrieved from http://www.sosyalbil.selcuk.edu.tr/sos_mak/makaleler.pdf

Coşkun, İ. (2007). Müşteri tatmini ve müşteri değerinin müşteri sadakati üzerine etkisi: Süpermarket ve bankacılık sektöründe bir araştırma. Eskişehir Osmangazi Üniversitesi, Sosyal Bilimler Enstitüsü. Unpublished Master's Thesis, Eskişehir.

Deloitte Liderlik Enstitüsü. (2013). Retrieved from https://www.deloitte.com

Demir, M. Ö. (2012). Marka sadakatinin ölçülmesi: Niyete bağlı tutumsal ölçek ile satın alma sırasına dayalı davranışsal ölçeğin karşılaştırılması. İstanbul Üniversitesi, İşletme Fakültesi Dergisi, 41(1), 103-128.

Dowling, G. R. (2004). Corporate reputations: Should you compete on yours? California Management Review, 46(3), 19-36. http://dx.doi.org/10.2307/41166219

Dursun, M. (2011). Müşterilerin kurumsal imaj algısının müşteri bağlllı̆̆ üzerindeki etkisi: Hizmet sektöründe bir araştırma. Yönetim, 22(69), 97-118.

Engel, J. F., Blackwell, R. D., \& Miniard, P. W. (1990). Consumer behavior (6th ed.). Chicago, IL: The Dryden Press.

Eryılmaz, M. E. (2008). Örgüt itibarı kavramı ve yönetimi ile ilgili bazı sorunlar. Anadolu Üniversitesi Sosyal Bilimler Dergisi, 1(8), 155-174.

Fombrun, C. J. (1996). Reputation: Realizing Value from the Corporate Image. Boston, MA: Harvard Business School Pres.

Gray, E. R., \& Balmer, J. M. T. (1998). Managing corporate image and corporate reputation. Long Range Planning, 31(5), 695-702. http://dx.doi.org/10.1016/S0024-6301(98)00074-0

Gronholdt, L., Martensen, A., \& Kristensen, K. (2000). The relationship between customer satisfaction and loyalty: Cross-industry differences. Total Quality Management \& Business Excellence, 11(4-6), 509-515. http://dx.doi.org/10.1080/09544120050007823

Guiltinan, J. P., Paul, G. W., \& Madden, T. J. (1994). Marketing management: Strategies and programs (5th ed.). US: McGraw-Hill.

Gün, F. S., Tosun, N., \& Özkaya, B. (2012, September 20-22). The new paradigm: Public relations managers' attitudes towards innovation in order to create brand reputation. Euprera 2012 Congress. İstanbul, Turkey: İstanbul Üniversitesi İletişim Fakültesi.

Herrbach, O., Mignonac, K., \& Gatignon, A. L. (2004). Exploring the role of perceived external prestige in 
managers' turnover intentions. International Journal of Human Resource Management, 15(3), 1390-1407. http://dx.doi.org/10.1080/0958519042000257995

Kabiraj, S., \& Shanmugan, J. (2010, February). Development of a conceptual framework for brand loyalty: A Euro-Mediterranean perspective received. Journal of Brand Management, 18(4/5), 285-299.

Karakılıç, N. Y. (2005). Kurumsal itibarın müşteri tercihleri üzerine etkileri: Afyon'da perakende sektöründe faaliyet gösteren işletmeler üzerine bir araştırma. Afyon Kocatepe Üniversitesi, Ikktisadi ve İdari Bilimler Fakültesi Dergisi, 7(2), 181-196.

Keller, K. L. (1998). Strategic brand management: Building, measuring, and managing brand equity. NJ: Prentice-Hall, U.S.A.

Keller, K. L. (2000). Building and Managing Corporate Brand Equity. In M. Schultz, M. J. Hatch, \& M. H. Larsen (Eds.), The expressive organization: Linking identity, reputation, and the corporate image (pp. 115-137). London: Oxford University Press.

Kesic, T., Kraljevic, S. S., \& Vlasic, G. (2005, January). Image as a competitive factor of retailing industry. Sixth International Conference on Enterprise in Transition, Marketing and Networking, 367-376.

Kılıç, S., \& Şenol, G. (2010). Gıda perakendeciliğinin gelişimi ve gıda perakendeciliğinde rekabeti etkileyen unsurlar. İsletme ve Ekonomi Araştırmaları Dergisi, 1(2), 45-62.

Köse, E. (2007). Müşteri sadakati sağlamada araçsal bir yöntem olarak şikayet yönetimi. Marmara Üniversitesi Sosyal Bilimler Enstitüsü. Unpublished Master's Thesis, İstanbul.

Marangoz, M., \& Biber, L. (2007, Aralık). Kurumsal imajın ve kurumsal ünün müşteri bağlılığına etkileri. Karamanoğlu Mehmetbey Üniversitesi, İktisadi ve İdari Bilimler Fakültesi, Sosyal ve Ekonomik Araștırmalar Dergisi, 173-193. Retrieved from http://iibfdergi.kmu.edu.tr/userfiles/file/aralik2007/PDF/ 9.pdf

Martenson, R. (2007). Corporate brand image, satisfaction and store loyalty: A study of the store as a brand, store brands and manufacturer brands. International Journal of Retail \& Distribution Management, 35(7), 544-555. http://dx.doi.org/10.1108/09590550710755921

Nunnally, J. C. (1978). Psychometric theory. New York: McGraw-Hill.

Okay, A. (1998). Halkla ilişkiler aracı olarak sponsorluk. İstanbul: Epsilon Yayıncılık.

Oliver, R. L. (1999). Whence consumer loyalty. Journal of Marketing, (63), 33-44. http://dx.doi.org/10.2307/125 2099

Öz, E. Ü., \& Bulutlar, F. (2009). Algılanan kurumsal itibar ve kurumdan ayrılma niyeti arasındaki ilişkide bir ara değişken olarak özdeşleşmenin rolü. Yönetim Araştırmaları Dergisi, 9(1), 35-52.

Özdemir, M., \& Koçak, A. (2012). İlişkisel pazarlama çerçevesinde marka sadakatinin oluşumu. Ankara Üniversitesi, Siyasal Bilgiler Fakültesi Dergisi, 67(2), 127-156. Retrieved from http://dergiler.ankara.edu.tr/dergiler/42/1669/17809.pdf

Perakende müşteri ilişkileri ve yönetimi: Müşteri tatminini ölçmek. (2010, Aralık). Retrieved from http://notoku.com/musteri-tatminini-olcmek/

Regenthal, G. (1992). Identitat und image-praxishilfen für das management in wirschaft. Bildung und Gesllschaft, Köln: Wirtschaftsverl. Bachem.

Tığlı, M. (2003). Kurumsal imaj kavramı ve sembolik analoji tekniği yoluyla Marmara Üniversitesi’nin kurumsal imajının belirlenmesine ilişkin bir uygulama. MarmaraÜniversitesi İktisadi ve İdari Bilimler Fakültesi Dergisi, 1(18), 245-256.

Tosun, N. (2010). Iletişsim temelli marka yönetimi. İstanbul: Beta Basım A.Ş.

Tsai, W., \& Yang, I. W. (2010, March). Does 1mage matter to different job applicants? The influences of corporate image and applicant individual differences on organizational attractiveness. International Journal of Selection and Assessment, 18(1), 48-63. http://dx.doi.org/10.1111/j.1468-2389.2010.00488.x

Usta, R., \& Memiş, S. (2009). Hizmet kalitesi ve marka bağlllığı arasındaki ilişki üzerine müşteri tatminin aracıllk etkisi. Atatürk Üniversitesi İktisadi ve İdari Bilimler Dergisi, 23(4), 87-108.

Wansink, B., \& Seed, S. (2001, February). Making brand loyalty programmes succeed. Journal of Brand Management, 8(3), 211-222. http://dx.doi.org/10.1057/palgrave.bm.2540021 
Weiwei, T. (2007, December). Impact of corporate 1mage and corporate reputation on customer loyalty: A review. Management Science and Engineering, 1(2), 57-62.

Yalçın, B. (2010, Nisan). Turizmde sürdürülebilir rekabet açısından işletmelerin kurumsal imajı ile ülke imajı arasındaki etkileşime yönelik bir değerlendirme. Dayanışma Dergisi, 108, 23-33.

Yalçın, M., Erdoğmuş, İ. E., \& Çobanoğlu, E. (2009). Müşteri faydasının müşteri tatmini ve bağlılı̆̆ı üzerine etkisi: Organize gıda perakendeci örneği. Marmara Üniversitesi İktisadi ve İdari Bilimler Fakültesi Dergisi, 26(1), 383-396.

Yücel, A., \& Yücel, N. (2012). Mağaza imajı ile mağaza sadakati arasındaki ilişsinin belirlenmesi: Denizli ilinde yapılan bir araştırma. Yönetim Bilimleri Dergisi, 10(19), 95-114.

\section{Copyrights}

Copyright for this article is retained by the author(s), with first publication rights granted to the journal.

This is an open-access article distributed under the terms and conditions of the Creative Commons Attribution license (http://creativecommons.org/licenses/by/3.0/). 